\title{
New Perspectives in Attention Deficit Hyperactivity Disorder: Possible Link to Oxytocin
}

\author{
Mazlum Çöpür ${ }^{1}$, Sidar Çöpür ${ }^{2}$ \\ ${ }^{1}$ Department of Psychology, Arel University, Istanbul, Turkey, ${ }^{2}$ Department of Medicine, \\ Koc University School of Medicine, Istanbul, Turkey
}

\section{Dear Editor-in-chief,}

Attention deficit hyperactivity disorder (ADHD) is the most common neurobehavioral disorder of childhood and characterized by symptoms of inattention, hyperactivity, impulsivity and oppositional behaviors [1]. Although the exact underlying pathophysiology of ADHD remains unknown, multiple genetic and environmental factors including prenatal alcohol or tobacco exposure, structural brain disorders, mutations at dopaminergic and serotonergic pathways, Turner syndrome, Tuberous Sclerosis Complex, Neurofibromatosis I and Fragile X syndrome have been implicated [2]. Obstetrical use of oxytocin has been proposed as potential risk factor in ADHD in few studies recently, however, a recent meta-analysis study demonstrated no statistically significant association [3]. Nevertheless, all studies conducted in this field are observational studies with low-to-middle scientific study quality and multiple interventional studies continue to be conducted.

As a nonapeptide, oxytocin, is primarily produced at paraventricular and supraoptic nuclei of hypothalamus and released from poste-

\section{Correspodence to:}

Mazlum Çöpür, MD

Department of Psychology, Arel

University, Istanbul, Turkey

Phone: +90 5053351162

E-mail: sidar1996@yahoo.com.tr rior pituitary gland. Predominant physiological functions include but not limited to childbirth and breastfeeding while additional roles in the field of neuropsychiatry have recently been described [4]. Binding of oxytocin to its' receptor, a G-protein coupled receptor (specifically $\mathrm{Gq}$ type) through inositol triphosphatediacylglycerol (IP3-DAG) second messenger system, is involved in pain sensation integration, limbic system regulation, social learning and sensation $[5,6]$. Projections of oxytocinproducing cells towards gamma-aminobutyric acid (GABA)-secreting interneurons at amygdala diminish output from amygdala which are crucial in emotions, social recognition and social learning $[7,8]$. Therefore, oxytocin signaling appears to modulate attention span and quality through limbic system, particularly amygdala [9]. Regarding its' central role in neurotransmission, oxytocin has been considered as novel therapeutic option for various neuropsychiatric disorders including major depression, postpartum depression, autism spectrum disorder, bipolar disorder and personality disorders [10-14].

Lower plasma levels of oxytocin have been recorded in patients with $\mathrm{ADHD}$ compared to controls $[15,16]$. In addition, lower levels of oxytocin are demonstrated in ADHD patients who are not on medication compared to ADHD patients that are on medication while negative correlation between serum oxyto- 
cin levels and ADHD-Rating Scale scores has been reported in a study conducted with 36 subjects with ADHD (23 non-medicated and 13 medicated subjects) and 22 age and sexmatched control subjects [15]. However, significant variations in between ADHD patients in terms of social skills, emotional control and social functioning are present which may be mainly due to different levels of serum oxytocin and genetic polymorphisms in oxytocin receptor gene. Higher serum levels of oxytocin are associated with better empathy skills, assessed via Bryant's Empathy Index for Children and Adolescents, and lower levels of aggression-impulsivity, assessed via Buss-Perry Aggression Questionnaire and Barratt impulsivity scale-11 in a study conducted with 40 male ADHD patients at age 7-18 [17,18]. Multiple single nucleotide polymorphisms (SNP) at oxytocin receptor (OXTR) have been identified and associated with various phenotypes. For instance, SNP rs4686302 is associated with differences in social cognition while SNP rs53576-rs2254298 are linked to social deficits [19-21].

As evidences accumulating about the role of oxytocin in ADHD, new therapeutic possibilities such as oxytocin administration and oxytocin receptor modulators have emerged.

\section{References}

1. Luo Y, Weibman D, Halperin JM, Li X. A review of heterogeneity in attention deficit/hyperactivity disorder (ADHD). Front Hum Neurosci. 2019;13:42.

2. Curatolo P, D'Agati E, Moavero R. The neurobiological basis of ADHD. Ital J Pediatr. 2010;36:79.

3. Lønfeldt NN, Verhulst FC, Strandberg-Larsen K, Plessen KJ, Lebowitz ER. Assessing risk of neurodevelopmental disorders after birth with oxytocin: a systematic review and meta-analysis. Psychol Med. 2019;49:881-90.

4. Ross HE, Cole CD, Smith Y, Neumann ID, Landgraf R, Murphy AZ, et al. Characterization of the oxytocin sys-
Commonly encountered adverse effects of intranasal oxytocin therapy in other fields are mild such as tiredness, nasal discomfort, diarrhea and skin irritation while severe side effects including seizures have rarely been reported [22]. However, no randomized-control trial (RCT) has fully examined such therapeutic approach yet while a double-blind placebocontrolled cross-over RCT investigating the efficiency and safety of intranasal oxytocin in adult patients with ADHD is registered and ongoing [23]. Even though the need for multiple large-scale RCT to evaluate the validity of oxytocin as a therapeutic option in ADHD is clear, it appears to be a promising therapeutic option that may influence future clinical practice

Keywords: attention deficit hyperactivity disorder; oxytocin; treatment

\section{Conflict of Interest}

All authors declare that they have no conflict of interest.

\section{Funding Sources}

This study was not funded by any grant. tem regulating affiliative behavior in female prairie voles. Neuroscience. 2009;16:892-903.

5. Busnelli M, Chini B. Molecular Basis of Oxytocin Receptor Signalling in the Brain: What We Know and What We Need to Know. Curr Top Behav Neurosci. 2018;35:3-29.

6. Fineberg SK, Ross DA. Oxytocin and the Social Brain. Biol Psychiatry. 2017;81:e19-e21.

7. Knobloch HS, Charlet A, Hoffmann LC, Eliava M, Khrulev S, Cetin AH, et al. Evoked axonal oxytocin release in the central amygdala attenuates fear response. Neuron. 2012;73:553-66. 
8. Marlin BJ, Froemke RC. O xytocin modulation of neural circuits for social behavior. Dev Neurobiol. 2017;77:16989.

9. Herpertz SC, Bertsch K. A New Perspective on the Pathophysiology of Borderline Personality Disorder: A Model of the Role of Oxytocin. Am J Psychiatry. 2015;172:840-51.

10. Yamasue H, Domes G. Oxytocin and Autism Spectrum Disorders. Curr Top Behav Neurosci. 2018;35:449-65.

11. Cardaillac C, Rua C, Simon EG, El-Hage W. Oxytocin and postpartum depression. J Gynecol Obstet Biol Reprod (Paris). 2016;45:786-95.

12. Bowen MT, Neumann ID. Rebalancing the Addicted Brain: Oxytocin Interference with the Neural Substrates of Addiction. Trends Neurosci. 2017;40:691-708.

13. Dinsdale NL, Crespi BJ. Revisiting the wandering womb: Oxytocin in endometriosis and bipolar disorder. Horm Behav. 2017;96:69-83.

Sasaki T, Hashimoto K, Oda Y, Ishima T, Kurata T, Takahashi J, et al. Decreased levels of serum oxytocin in pediatric patients with Attention Deficit/Hyperactivity Disorder. Psychiatry Res. 2015;228:746-51.

14. Lien YJ, Chang HH, Tsai HC, Kuang Yang Y, Lu RB, See Chen P. Plasma oxytocin levels in major depressive and bipolar II disorders. Psychiatry Res. 2017;258:402-6.

15. Sasaki T, Hashimoto K, Oda Y, Ishima T, Kurata T, Takahashi J, et al. Decreased levels of serum oxytocin in pediatric patients with Attention Deficit/Hyperactivity Disorder. Psychiatry Res. 2015;228:746-51.

16. Işık Ü, Bilgiç A, Toker A, Kılınç I. Serum levels of cortisol, dehydroepiandrosterone, and oxytocin in children with attention-deficit/hyperactivity disorder combined presentation with and without comorbid conduct disorder. Psychiatry Res. 2018;261:212-9.

17. Demirci E, Ozmen S, Kilic E, Oztop DB. The relationship between aggression, empathy skills and serum oxytocin levels in male children and adolescents with attention deficit and hyperactivity disorder. Behav Pharmacol. 2016;27:681-8.

18. Demirci E, Özmen S, Öztop DB. Relationship between Impulsivity and Serum Oxytocin in Male Children and Adolescents with Attention-Deficit and Hyperactivity Disorder: A Preliminary Study. Noro Psikiyatr Ars. 2016;53:291-5.

19. Kalyoncu T, Özbaran B, Köse S, Onay H. Variation in the Oxytocin Receptor Gene Is Associated With Social Cognition and ADHD. J Atten Disord. 2019;23:702-11.

20. Ayaz AB, Karkucak M, Ayaz M, Gokce S, Kayan E, Güler EE, et al. Oxytocin system social function impacts in children with attention-deficit/hyperactivity disorder. Am J Med Genet B Neuropsychiatr Genet. 2015;168:609-16.

21. Baribeau DA, Dupuis A, Paton TA, Scherer SW, Schachar RJ, Arnold PD, et al. Oxytocin Receptor Polymorphisms are Differentially Associated with Social Abilities across Neurodevelopmental Disorders. Sci Rep. 2017;7:11618-.

22. Cai Q, Feng L, Yap KZ. Systematic review and metaanalysis of reported adverse events of long-term intranasal oxytocin treatment for autism spectrum disorder. Psychiatry Clin Neurosci. 2018;72:140-51.

23. Oxytocin and Cognitive Control in Adult ADHD [Internet]. 2019. [cited October 24th] Available from: https:// clinicaltrials.gov/ct2/show/NCT03136263. 
